\title{
Characterization of multiple isolates from an Alexandrium ostenfeldii bloom in The Netherlands
}

\author{
Dedmer B. Van de Waal ${ }^{\mathrm{a}, *}$, Urban Tillmann ${ }^{\mathrm{b}}$, Helge Martens ${ }^{\mathrm{b}}$, Bernd Krock ${ }^{\mathrm{b}}$, \\ Yvonne van Scheppingen ${ }^{c}$, Uwe John ${ }^{\mathrm{b}}$ \\ ${ }^{a}$ Department of Aquatic Ecology, Netherlands Institute of Ecology, PO Box 50, 6700 AB Wageningen, The Netherlands \\ ${ }^{\mathrm{b}}$ Alfred Wegener Institute Helmholtz Centre for Polar and Marine Research, Am Handelshafen 12, 27570 Bremerhaven, Germany \\ ${ }^{\mathrm{c}}$ Waterschap Scheldestromen, PO Box 1000, 4330 ZW Middelburg, The Netherlands
}

\section{A R T I C L E I N F O}

\section{Article history:}

Received 23 December 2014

Received in revised form 21 August 2015

Accepted 21 August 2015

\section{Keywords:}

Harmful algal blooms

PSP toxins

Spirolide

Gymnodimine

Lytic activity

Allelochemical potency

\begin{abstract}
A B S T R A C T
Alexandrium ostenfeldii is an emerging harmful algal bloom species forming a global threat to coastal marine ecosystems, with consequences for fisheries and shellfish production. The Oosterschelde estuary is a shallow, macrotidal and mesotrophic estuary in the southwest of The Netherlands with large stocks of mussels, oysters, and cockles. These shellfish stocks were threatened by a recent $A$. ostenfeldii bloom in the Ouwerkerkse Kreek, which is a brackish water creek discharging water into the Oosterschelde. Little is yet known about the characteristics of the A. ostenfeldii population in this creek. We therefore isolated 20 clones during an $A$. ostenfeldii bloom in 2013, and characterized these clones on their growth and toxin profile in their exponential growth phase. The cyclic imines were identified by comparison of $A$. ostenfeldii extracts with the retention time and CID spectra of standard solutions, or with published CID spectra. We furthermore assessed the allelochemical potency and phylogeny of a selection of 10-12 clones. Morphology and molecular phylogeny showed that all clones belong to Group 1 of $A$. ostenfeldii. All clones showed comparable growth rates of on average $0.22 \pm 0.03 \mathrm{~d}^{-1}$. During exponential growth, they all produced a unique combination of paralytic shellfish poisoning toxins, spirolides and gymnodimines, of which particularly the latter showed a high intra-specific variability, with a 25 -fold difference between clones with the lowest and highest cell quota. Furthermore, the selected 12 clones showed high allelopathic potencies with $\mathrm{EC}_{50}$ values based on lysis assays against the cryptophyte Rhodomonas salina between 212 and 525 A. ostenfeldii cells $\mathrm{mL}^{-1}$. Lytic activities were lower for cell extracts, indicating an important extracellular role of these compounds. A high intra-specific variability may add to the success of genotypically diverse A. ostenfeldii blooms, and make populations resilient to changes in environmental and climatic conditions.
\end{abstract}

(c) 2015 Elsevier B.V. All rights reserved.

\section{Introduction}

Harmful algal blooms are a global threat to coastal marine ecosystems, with consequences for fisheries and shellfish production (Anderson et al., 2002; Heisler et al., 2008; Wang, 2008). Alexandrium is among the most common bloom forming toxic dinoflagellate genera and is generally held responsible for the outbreak of paralytic shellfish poisoning (PSP; Anderson et al., 2012). Besides PSP toxins, some Alexandrium species are known to produce other toxins including different spirolides (SPX) or gymnodimines (Cembella, 2003; Van Wagoner et al., 2011;

\footnotetext{
* Corresponding author. Tel.: +31317473553.

E-mail address: d.vandewaal@nioo.knaw.nl (D.B. Van de Waal).
}

Borkman et al., 2012; Kremp et al., 2014). These species belong to different phylogenetic groups of Alexandrium ostenfeldii as recently defined by Kremp et al. (2014), including Alexandrium peruvianum. Most $A$. ostenfeldii strains have been shown to produce SPX, some strains also produce detectable amounts of PSP toxins, while only a few strains were reported to combine PSP toxin, SPX and 12-methylgymnodimine production (Cembella, 2003; Borkman et al., 2012; Kremp et al., 2014).

PSP toxins are a group of neurotoxic compounds, including saxitoxin (STX), neosaxitoxin (NEO), gonyautoxins (GTX), and their N-sulfocarbamoyl variants the B- and C-toxins (Shimizu, 1996; Cembella, 1998). STX is highly toxic with an $\mathrm{LD}_{50}$ value (i.p. mice) of $8 \mu \mathrm{g} \mathrm{kg}^{-1}$ body weight (Wiberg and Stephenson, 1960). The addition of a sulfate group at the $\mathrm{C}-11$ position forms GTX, thereby reducing the toxicity by up to $40 \%$. A further addition of a sulfonyl 
group at the carbamoyl group forms C-toxins, which exhibit a 99\% lower toxicity as compared to STX (Wiese et al., 2010). SPX and gymnodimines are fast acting highly toxic neurotoxins, with $\mathrm{LD}_{50}$ values (i.p. mice) down to 6.9 and $96 \mu \mathrm{g} \mathrm{kg}^{-1}$ body weight, respectively (Munday et al., 2004, 2012). Besides toxicity, various Alexandrium species were shown to have allelopathic potencies toward grazers and other phytoplankton species (Tillmann and John, 2002; Tillmann et al., 2007, 2008; John et al., 2015).

Alexandrium ostenfeldii is globally distributed in brackish and marine environments, and isolates have been characterized from locations worldwide (Kremp et al., 2014). A. ostenfeldii is historically seen as background bloomer (Cembella et al., 2000; John et al., 2003), however, dense A. ostenfeldii blooms have been reported recently in the Narragansett Bay and the New River Estuary in the U.S. east coast (Borkman et al., 2012; Tomas et al., 2012), the Baltic Sea coast of Finland (Hakanen et al., 2012), along the Adriatic coast of Italy (Ciminiello et al., 2006), and recently in a creek of the Oosterschelde estuary in the Southwest of The Netherlands (Burson et al., 2014). This Oosterschelde estuary is a shallow, macrotidal and mesotrophic estuary with large stocks of mussels, oysters, and cockles (Fig. 1A and B; Troost et al., 2010; van Broekhoven et al., 2014). Because of potential contamination of these shellfish with phytoplankton toxins, The Netherlands has a regular monitoring program for toxic compounds in shellfish, as well as for the occurrence of harmful algal species in the Oosterschelde estuary (van der Fels-Klerx et al., 2011). A recent dense $A$. ostenfeldii bloom in a creek discharging water into the Oosterschelde threatened the shellfish stocks, and was terminated by the addition of hydrogen peroxide (Burson et al., 2014). The bloom, however, recurred in 2013 and reached population densities of up to 4500 cells $\mathrm{mL}^{-1}$ (Fig. 1C). Little is yet known about the characteristics of the $A$. ostenfeldii population in the creek. We therefore isolated a number of $A$. ostenfeldii clones during the bloom in 2013, and characterized the bloom population in terms of growth, morphology, phylogeny, toxin composition, and lytic activity.

\section{Material and methods}

\subsection{Field sampling}

The Ouwerkerkse Kreek is a small brackish water creek in the province of Zeeland, Southwest of The Netherlands (Fig. 1A and B; See also Burson et al., 2014). The inlet of the creek is connected with ditches that drain the agricultural lands in the area, and water from the creek is regularly discharged into the Oosterschelde estuary via a pumping station. The phytoplankton population in the creek was monitored for Alexandrium ostenfeldii, and weekly samples were taken for cell counts during the bloom. An integrated water sample was taken of the upper $1 \mathrm{~m}$ of the water column at location 'a' (Fig. 1B), and a $1 \mathrm{~L}$ sub sample was fixed with Lugol's iodine solution (Lugol) to a final concentration of $1 \%$. A. ostenfeldii cells were counted in a Sedgewick chamber on an inverted microscope (Olympus Vanox, Hamburg, Germany). Isolates of $A$. ostenfeldii cells were sampled at the onset of the bloom on 16 July 2013 from locations 'a' and 'b' in the creek (Fig. 1B).

\subsection{Isolation}

Cells of Alexandrium ostenfeldii were picked from small droplets in a petridish using a Pasteur pipette or a $10 \mu \mathrm{L}$ mirco-pipette. Individual cells were cleaned five times in $2 \mu \mathrm{L}$ droplets of sterile medium consisting of filtered and diluted North Sea water with a salinity of about 10 , or in sterilized artificial brackish water medium with a salinity of about 10 (Appendix A). Both media contained nutrients corresponding to $50 \%$ of K-medium (Keller et al., 1987). A. ostenfeldii cells were subsequently grown in $100 \mu \mathrm{L}$ medium mixed in a 1:1 ratio with sterile filtered water from the creek $(0.2 \mu \mathrm{m}$ membrane filter) in microplate wells. Clones OKNL1-10 were subsequently cultured in artificial brackish water medium (Appendix A), and clones ONNL11-22 in diluted North Sea water medium.

\subsection{Culturing of clones}

Twenty of the successfully isolated clones were grown in $250 \mathrm{~mL}$ Erlenmeyer flasks at $15^{\circ} \mathrm{C}$ under an incident light intensity of $100 \mu \mathrm{mol}$ photons $\mathrm{m}^{-2} \mathrm{~s}^{-1}$ at a light-dark cycle of $16: 8$. After acclimation to these growth conditions (i.e. $>5$ generations), cells were transferred and growth was monitored by cell counts performed every second day. At mid-exponential phase ( $\sim 6000$ cells $\mathrm{mL}^{-1}$ ) cultures were harvested for analysis of toxins and for cell size measurements. Cultures were counted again two days later, confirming that cell sampling two days before was still during the exponential phase. For toxin sampling, $15 \mathrm{~mL}$ samples were taken for extraction of SPX and gymnodimines, and $50 \mathrm{~mL}$ samples each were taken for PSP toxin and DNA extraction. Samples were centrifuged at $6800 \times g$ for $15 \mathrm{~min}$ (SL16, Thermo Scientific, Waltham, USA) and after removal of the supernatant the pellets were stored at $-20^{\circ} \mathrm{C}$.

\subsection{Cell counts and measurements}

Cell densities of Alexandrium ostenfeldii cultures were determined by using sedimentation chambers for settling $0.2-1 \mathrm{~mL}$ of culture suspension, and subareas with at least 400 cells were counted with an inverted microscope (20X, Zeiss Axiovert 40C). Observation and documentation of live and fixed cells was carried
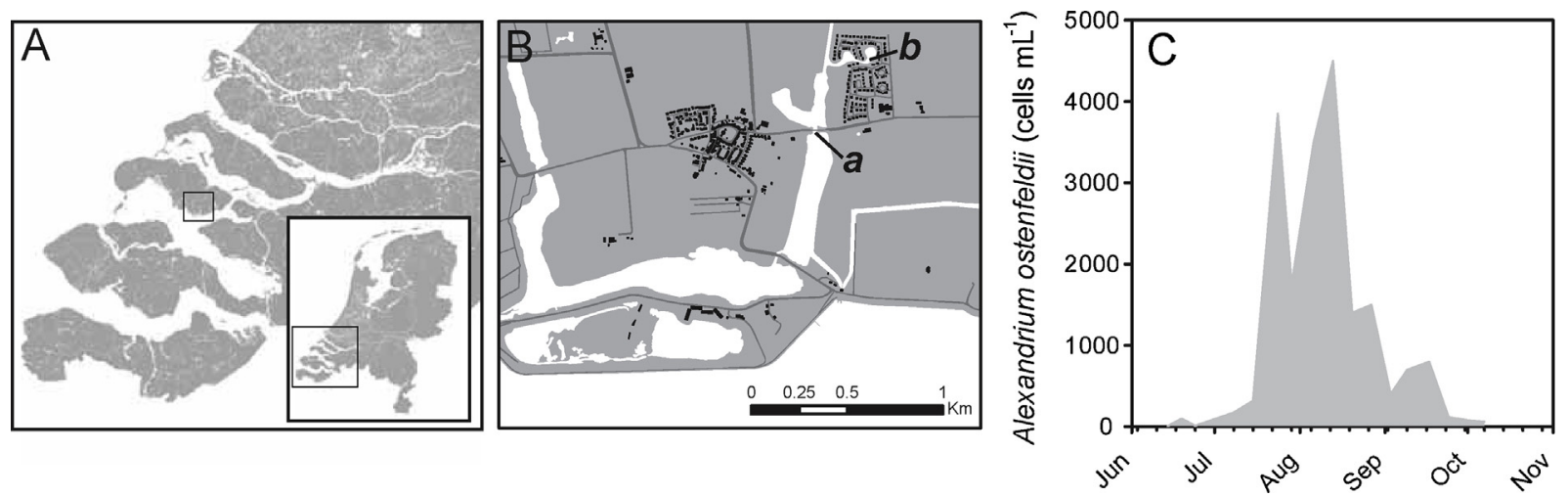

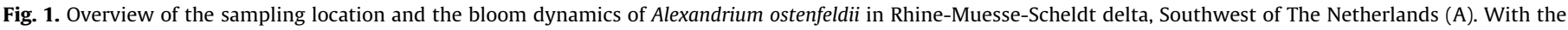
specific sampling locations ' $a$ ' and 'b' in the Ouwerkerkse Kreek (B), and the A. ostenfeldii population densities during the 2013 bloom sampled from location 'a' (C). 
out with either an inverted microscope (Axiovert 200M, Zeiss, Germany) or a Zeiss Axioskop 2 (Zeiss, Germany), both equipped with epifluorescence and differential interference contrast optics. Length and width of cells ( $n>50$ from each clone) were measured on freshly Lugol-fixed cells (1\% final concentration) with the program AxioVs40 (v.4.8., Zeiss, Göttingen, Germany) using micrographs taken with a digital camera (Axiocam MRc, Zeiss, Göttingen, Germany).

Growth rates were estimated for each clone by means of an exponential function fitted through all cell counts over time $(n=4)$, according to $N_{t}=N_{0} \exp ^{\mu t}$, where $N_{t}$ refers to the cell concentrations at time $t, N_{0}$ to the cell concentrations at the start of the experiment, and $\mu$ to the growth rate.

\subsection{Cell morphology and morphometry}

Pattern, shape and dimension of thecal plates were examined using epifluorescence microscopy of calcofluor-stained cells according to the method of Fritz and Triemer (1985). Morphometric measurements were performed for four randomly selected clones (OKNL11, 12, 14, 19). Cells of exponentially growing cultures were fixed with neutral Lugol ( $1 \%$ final concentration) for $1 \mathrm{~h}$ and then collected by centrifugation at $3220 \times \mathrm{g}$ for $10 \mathrm{~min}$ (Eppendorf 5810R, Hamburg, Germany). Cells were resuspended in a drop of filtered seawater and a drop of a $1 \mathrm{mg} \mathrm{mL}^{-1}$ solution of Fluorescence Brightner 28 (Sigma-Aldrich, St. Louis, MO, USA) on a microscope slide. Cells were inspected at $1000 \times$ magnification (Zeiss, Axioskop 2, Göttingen, Germany) and photographed with a digital camera (Axiocam MRc, Zeiss, Göttingen). Measurements of size and area of selected diagnostic plates were performed with the program AxioVs40 (v.4.8., Zeiss, Göttingen). Shape of the first apical plate and the anterior sulcal plate was scored into categories given by Kremp et al. (2014).

\subsection{Toxins}

\subsubsection{Toxin extraction}

Freeze dried cell pellets were suspended in $500 \mu \mathrm{L} 0.03 \mathrm{M}$ acetic acid for PSP toxin analysis and with methanol for SPX analysis, respectively. The samples were subsequently transferred into a FastPrep tube containing $0.9 \mathrm{~g}$ of lysing matrix D. The samples were homogenized by reciprocal shaking at maximum speed $\left(6.5 \mathrm{~m} \mathrm{~s}^{-1}\right)$ for $45 \mathrm{~s}$ in a Bio101 FastPrep instrument (Thermo Savant, Illkirch, France). After homogenization, samples were centrifuged (Eppendorf 5415 R, Hamburg, Germany) at 16,100 $\times g$ at $4{ }^{\circ} \mathrm{C}$ for $15 \mathrm{~min}$. The supernatants were transferred to spin-filters (pore-size $0.45 \mu \mathrm{m}$, Millipore Ultrafree, Eschborn, Germany) and centrifuged for $30 \mathrm{~s}$ at $800 \times \mathrm{g}$. The filtrates were transferred to HPLC vials and stored at $-20^{\circ} \mathrm{C}$ until measurement. Variation in cellular toxin quota and composition was tested by growing four clones in triplicate.

\subsubsection{Toxin analysis}

2.6.2.1. PSP toxins. The aqueous extracts were analyzed for PSP toxins by reverse-phase ion-pair liquid chromatography with fluorescence detection (LC-FLD) and post-column derivatization following minor modifications of previously published methods (Diener et al., 2006; Krock et al., 2007). The LC-FLD analysis was carried out on a LC1100 series liquid chromatography system consisting of a G1379A degasser, a G1311A quaternary pump, a G1229A autosampler, and a G1321A fluorescence detector (Agilent Technologies, Waldbronn, Germany), equipped with a Phenomenex Luna C18 reversed-phase column $(250 \mathrm{~mm} \times 4.6 \mathrm{~mm}$ id, $5 \mu \mathrm{m}$ pore size) (Phenomenex, Aschaffenburg, Germany) with a Phenomenex SecuriGuard precolumn. The column was coupled to a PCX 2500 post-column derivatization system (Pickering Laboratories, Mountain View, CA, USA). Eluent A contained $6 \mathrm{mM}$ octanesulfonic acid, $6 \mathrm{mM}$ heptanesulfonic acid, $40 \mathrm{mM}$ ammonium phosphate, adjusted to $\mathrm{pH} 6.95$ with dilute phosphoric acid, and $0.75 \%$ tetrahydrofurane. Eluent B contained $13 \mathrm{mM}$ octanesulfonic acid, $50 \mathrm{mM}$ phosphoric acid, adjusted to $\mathrm{pH} 6.9$ with ammonium hydroxide, $15 \%$ acetonitrile and $1.5 \%$ tetrahydrofur-

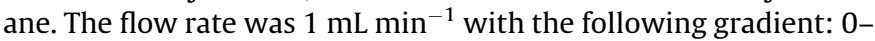
15 min isocratic $A, 15-16$ min switch to $B, 16-35$ min isocratic $B$, 35-36 min switch to A, 36-45 min isocratic A. The injection volume was $20 \mu \mathrm{L}$ and the autosampler was cooled to $4{ }^{\circ} \mathrm{C}$. The eluate from the column was oxidized with $10 \mathrm{mM}$ periodic acid in $555 \mathrm{mM}$ ammonium hydroxide before entering the $50{ }^{\circ} \mathrm{C}$ reaction coil, after which it was acidified with $0.75 \mathrm{M}$ nitric acid. Both the oxidizing and acidifying reagents entered the system at a rate of $0.4 \mathrm{~mL} \mathrm{~min}^{-1}$. The toxins were detected by dual-monochromator fluorescence $\left(\lambda_{\text {ex }} 333 \mathrm{~nm} ; \lambda_{\mathrm{em}} 395 \mathrm{~nm}\right.$ ). The data were processed with Agilent Chemstation software and calibrated against external standards. Standard solutions of PSP toxins were purchased from the Certified Reference Material Program of the Institute of Marine Biosciences (National Research Council, Halifax, NS, Canada).

\subsubsection{Lipophilic toxins.}

2.6.2.2.1. Selected reaction monitoring (SRM) experiments. Mass spectral experiments for lipophilic toxin detection and quantification were performed on a 4000 Q Trap (AB-SCIEX, Darmstadt, Germany), triple quadrupole mass spectrometer equipped with a TurboSpray ${ }^{\circledR}$ interface coupled to an Agilent (Waldbronn, Germany) model 1100 LC. The LC equipment included a solvent reservoir, in-line degasser (G1379A), binary pump (G1311A), refrigerated autosampler (G1329A/G1330B), and temperaturecontrolled column oven (G1316A).

After injection of $5 \mu \mathrm{l}$ of sample, separation of lipophilic toxins was performed by reverse-phase chromatography on a C8 column $(50 \times 2 \mathrm{~mm}$ ) packed with $3 \mu \mathrm{m}$ Hypersil BDS $120 \AA$ (Phenomenex, Aschaffenburg, Germany) and maintained at $25^{\circ} \mathrm{C}$. The flow rate was $0.2 \mathrm{~mL} \mathrm{~min}^{-1}$ and gradient elution was performed with two eluents, where eluent A was water and eluent B was methanol/ water $(95: 5, \mathrm{v} / \mathrm{v})$, both containing $2.0 \mathrm{mM}$ ammonium formate and $50 \mathrm{mM}$ formic acid. Initial conditions were elution with $5 \% \mathrm{~B}$, followed by a linear gradient to $100 \% \mathrm{~B}$ within $10 \mathrm{~min}$ and isocratic elution until 10 min with $100 \% \mathrm{~B}$. The program was then returned to initial conditions within $1 \mathrm{~min}$ followed by $9 \mathrm{~min}$ column equilibration (total run time: $30 \mathrm{~min}$ ).

Mass spectrometric parameters were as follows: curtain gas: 20 psi, CAD gas: medium, ion spray voltage: $5500 \mathrm{~V}$, temperature: $650{ }^{\circ} \mathrm{C}$, nebulizer gas: $40 \mathrm{psi}$, auxiliary gas: $70 \mathrm{psi}$, interface heater: on, declustering potential: $121 \mathrm{~V}$, entrance potential: $10 \mathrm{~V}$, exit potential: $22 \mathrm{~V}$, collision energy: $57 \mathrm{~V}$. SRM experiments were carried out in positive ion mode by selecting the following transitions (precursor ion $>$ fragment ion): $\mathrm{m} / \mathrm{z}$ $508>490$ for gymnodimine A, $522>504$ for 12-methylgymnodimine, $692>164$ for 13-desmethylspirolide C (SPX-1), and $694>164$ for 13-desmethylspirolide D. Dwell times of $40 \mathrm{~ms}$ were used for each transition. Standard solutions of SPX-1 and gymnodimine A were purchased from the Certified Reference Material Program of the Institute of Marine Biosciences (National Research Council, Halifax, NS, Canada), and 12methylgymnodimine was kindly provided by Kirsi Harju, VERIFIN, Department of Chemistry, University of Helsinki, Finland.

2.6.2.2.2. Product ion spectra. Product ion spectra were recorded in the Enhanced Product Ion (EPI) mode in the mass range from $\mathrm{m} / \mathrm{z} 120$ to 550. Positive ionization and unit resolution mode were used. The mass spectral parameters were as in SRM experiments. 


\subsection{Rhodomonas salina bioassays}

Clonal isolates of Alexandrium ostenfeldii (OKNL11-22) were grown in batch cultures in $100 \mathrm{~mL}$ Erlenmeyer flasks at standard culture conditions described above. Growth was followed by counting Lugol-fixed ( $1 \%$ final concentration) samples every second or third day using an inverted microscope. At late exponential phase, at a population density of $8-12 \times 10^{3}$ cells $\mathrm{mL}^{-1}$, cells were harvested for estimating both lytic capacity of whole cell cultures and of cell extracts. A subsample of $20 \mathrm{~mL}$ live sample was taken for whole cell lytic activity. A subsample of $50 \mathrm{~mL}$ was collected by centrifugation (Eppendorf 5810R, Hamburg, Germany at $3220 \times \mathrm{g}$ for $10 \mathrm{~min}$ ). The cell pellet was transferred to a $1 \mathrm{~mL}$ microtube, centrifuged again (Eppendorf 5415, 16,000 $\times \mathrm{g}, 5 \mathrm{~min}$ ), and stored frozen $\left(-20^{\circ} \mathrm{C}\right)$ until use.

Lytic activity of whole cell culture and cell extract were both estimated by a Rhodomonas salina lysis assay (Tillmann et al., 2009). For this bioassay, $R$. salina (strain KAC30, Kalmar culture collection, Sweden) was pre-adapted to and subsequently grown in 10 PSU medium for at least four weeks. For testing the variation in lytic activity, a full dose-response-curve of lytic activity of whole culture and cell extract was recorded for triplicate cultures of clone OKNL19. Here, nine different dilutions ranging from 4000 to 50 cells $\mathrm{mL}^{-1}$ and from 30,000 to 100 cells $\mathrm{mL}^{-1}$ for whole culture and cell extract, respectively, were prepared in triplicate and processed as described below. Lytic activity of all other clones was estimated with a reduced number of dilutions. For whole cell culture lysis estimates, four different dilutions of the Alexandrium ostenfeldii live samples were prepared (undiluted, 3000,1000 , and 250 cells $\mathrm{mL}^{-1}$; final concentration in the assay) in triplicate volumes of $3.9 \mathrm{~mL}$ in $6 \mathrm{~mL}$ glass vials. Each sample was spiked with $0.1 \mathrm{~mL}$ of a pre-adjusted culture of $R$. salina yielding a final concentration of $10 \times 10^{4}$ cells $\mathrm{mL}^{-1}$. The first of two negative controls contained only K-medium, whereas the second negative control was performed with Alexandrium tamarense, strain Alex5, a strain which previously was shown to be nonlytic (Tillmann and Hansen, 2009). Vials were then incubated at $15{ }^{\circ} \mathrm{C}$ in the dark. After $24 \mathrm{~h}$, samples were fixed with Lugol ( $2 \%$ final concentration), and concentrations of intact cells of both species were determined under an inverted microscope.

For estimating lytic activity of cell extracts, cell pellets were thawed and re-suspended in $1 \mathrm{~mL}$ filtered seawater. Cellular extracts were prepared by sonicating the cell suspension with a Sonoplus HD70 disintegrator equipped with a MS73 sonotrode for 1 min on ice using the following settings: $50 \%$ pulse cycle, $70 \%$ amplitude. Based on the known number of cells in the pellet, the extract was used to prepare four concentrations of "Alexandrium ostenfeldii cells" in the $4 \mathrm{~mL}$ volume used in the bioassays $(15,000$, 7000,3000 , and 1500 cells $\mathrm{mL}^{-1}$ ). The bioassays were then performed as described above except that just intact cells of Rhodomonas salina were counted.

All results were reported as final concentration of Rhodomonas salina expressed as percent of the seawater control. The data from each clone were plotted as log-transformed cell concentrations of Alexandrium ostenfeldii and corresponding percentage survival of $R$. salina (mean of three replicates). Data, even if a limited number of dilutions were performed, followed a sigmoid curve and were fitted as a dose-response curve with Eq. (1) in order to estimate the $\mathrm{EC}_{50}$ of $A$. ostenfeldii, defined as the concentration of $A$. ostenfeldii cells resulting in a mortality of $50 \%$ of the $R$. salina population.

$Y=\frac{100}{1+\left(\frac{X}{E C_{50}}\right)^{k}}$

Here, $Y$ is the concentration of intact Rhodomonas salina cells (as percentage of the control), $X$ is log-transformed cell concentration of Alexandrium ostenfeldii, and $\mathrm{EC}_{50}$ and $k$ are fitted parameters.
For the cell extract of clone OKNL18, $\mathrm{EC}_{50}$ calculation by curve fitting failed as the highest dose $\left(15,000\right.$ cells $\left.\mathrm{mL}^{-1}\right)$ yielded just $41 \%$ cell lysis. $\mathrm{EC}_{50}$ here was defined as " $>15,000$ cells $\mathrm{mL}^{-1}$ ".

\subsection{Phylogeny}

Ribosomal DNA sequence data for the phylogenetic analyses were obtained from Alexandrium ostenfeldii clones OKNL11-22. Initially, $50 \mathrm{~mL}$ samples of exponentially growing cells were collected by centrifugation at $3220 \times g$ for $15 \mathrm{~min}$ at room temperature (Eppendorf 5810R, Hamburg, Germany). The cell pellets were frozen at $-20^{\circ} \mathrm{C}$ for 20 min before extraction of total DNA with the DNeasy Mini Kit (Qiagen, Hilden, Germany) according to the manufacturer's instructions. The purity and quantity of the DNA was assessed by UV-spectroscopy with a NanoDrop ND-1000 system (Peqlab, Erlangen, Germany) and the integrity of DNA was confirmed using 1\% agarose gel electrophoresis where a majority of the extracted genomic DNA exceeded 20 kilobases.

The D1/D2 regions of the $28 \mathrm{~S}$ large subunit (LSU) ribosomal DNA and the internal transcribed spacer region, including the ITS1, 5.8S subunit, and ITS2 sequences loci were amplified from each total DNA extract by polymerase chain reaction (PCR). The forward and reverse primers for LSU amplification were: D1R-F ( $5^{\prime}$-ACC CGC TGA ATT TAA GCA TA- $\left.3^{\prime}\right)$ and D2C-R ( $5^{\prime}$-CCT TGG TCC GTG TTT CAA GA-3'), respectively. The forward and reverse primers for ITS/ 5.8 amplification were: ITS a (5'-CCA AGC TTC TAG ATC GTA ACA AGG (ACT)TC CGT AGG T-3') and ITS b (5'-CCT GCA GTC GAC A(GT)A TGC TTA A(AG)T TCA GC(AG) GG-3'), respectively. Reaction conditions were as follows: HotMasterTaq ${ }^{\circledR}$ (5Prime, Hamburg, Germany) buffer 1X, $0.1 \mathrm{mM}$ of dNTPs, $0.1 \mathrm{mM}$ of each forward and reverse primer and 1.25 units of Taq polymerase were added to 10$30 \mathrm{ng}$ of the extracted genomic DNA in total reaction volumes of $50 \mu \mathrm{L}$. For $28 \mathrm{~S}$ rDNA amplifications, the reactions were subjected to the following thermo cycling conditions: one cycle at $95{ }^{\circ} \mathrm{C}$ for $7 \mathrm{~min}, 35$ cycles at $94^{\circ} \mathrm{C}$ for $45 \mathrm{~s}$, at $54^{\circ} \mathrm{C}$ for $2 \mathrm{~min}$, and at $70{ }^{\circ} \mathrm{C}$ for $1.5 \mathrm{~min}$, and a final extension at $70^{\circ} \mathrm{C}$ for $5 \mathrm{~min}$. The thermal cycling conditions for the ITS/5.8 amplifications were: one cycle at $94{ }^{\circ} \mathrm{C}$ for $4 \mathrm{~min}, 9$ cycles at $94^{\circ} \mathrm{C}$ for $50 \mathrm{~s}$, at $60^{\circ} \mathrm{C}$ for $40 \mathrm{~s}$ and at $70{ }^{\circ} \mathrm{C}$ for $1 \mathrm{~min}$, and 29 cycles at $94{ }^{\circ} \mathrm{C}$ for $45 \mathrm{~s}$, at $50{ }^{\circ} \mathrm{C}$ for $45 \mathrm{~s}$, and at $70{ }^{\circ} \mathrm{C}$ for $1 \mathrm{~min}$, and a final $5 \mathrm{~min}$ extension step at $70^{\circ} \mathrm{C}$. Samples were kept at $10^{\circ} \mathrm{C}$ until analysis on $1 \%$ agarose gel, in order to ensure the expected amplification products were present. After PCR amplification and subsequent cloning into the vector provided with the TOPO TA Cloning ${ }^{\circledR}$ kit (Invitrogen, Carlsbad, California, USA), 3-8 clones per amplicon were sequenced using the M13 vector primers supplied with the kit. Sequencing was conducted with a standard cycle sequencing chemistry ABI 3.1 (Applied Biosystems, Darmstadt, Germany). Cycle sequencing products were analyzed on an ABI 3130 XL capillary sequencer (Applied Biosystems, Darmstadt, Germany) and the generated sequences were assembled with CLC main workbench version 6.0 (www.CLCbio.com). The resulting sequences were submitted to GenBank (Appendix B).

The LSU and ITS $/ 5.8 \mathrm{~S}$ sequences were then combined with those available in GenBank (Appendix B) and a combined alignments of LSU and ITS sequences was constructed in order to conduct phylogenetic analyses (Appendix C). The data set was aligned with MAFFT using the q-insi option (Katoh et al., 2005). The full ML analysis (GTRGAMMA, 1000 bootstrap replicates) was conducted with RAxML (Stamatakis et al., 2005).

\subsection{Statistical analysis}

Normality of cell size parameters (length, width, length/width ratio, and volume), toxins (PSP toxins, SPX and gymnodimines) and 
lytic activity was tested using the Shapiro-Wilk test. Significance of differences between clones was tested using a one-way ANOVA if the data was normal distributed, and a Kruskal-Wallis test if the distribution was non-normal. The associations between the cellular quota of the different toxins were tested using Pearson product-moment correlation.

\section{Results}

3.1. Growth, morphology, morphometry, and phylogeny

Growth rates for all isolates were comparable and ranged between $0.16^{-1}$ and $0.26^{-1}$ with an average of $0.22 \pm 0.03 \mathrm{~d}^{-1}$ $(n=20)$. Generally, cells were round to ellipsoid in shape (Fig. 2AF). The epitheca was slightly variable in shape with an outline ranging from sigmoid to dome-shape or round (Fig. 2B-F). The generally round hypotheca occasionally was slightly asymmetric (Fig. 2K). Within and among clones there was also a considerable variability in size (Fig. 2G-K, Table 1). Cell length of all measured cells ranged from 26.3 to $53.4 \mu \mathrm{m}$, the width from 30.6 to $40.5 \mu \mathrm{m}$, and the length/ width ratio from 0.9 to 1.2 with significant differences among clones in mean cell length (Kruskal-Wallis test; $H=259 ; \mathrm{d} f=19 ; P<0.001$ ), width (Kruskal-Wallis test; $H=322 ; \mathrm{d} f=19 ; P<0.001$ ), and length/ width ratios (Kruskal-Wallis test; $H=175 ; \mathrm{d} f=19 ; P<0.001$ ).

The plate pattern with a pore plate, 4 apical, 6 precingular, 5 postcingular, 2 antapical, 6 cingular, and 8 sulcal plates

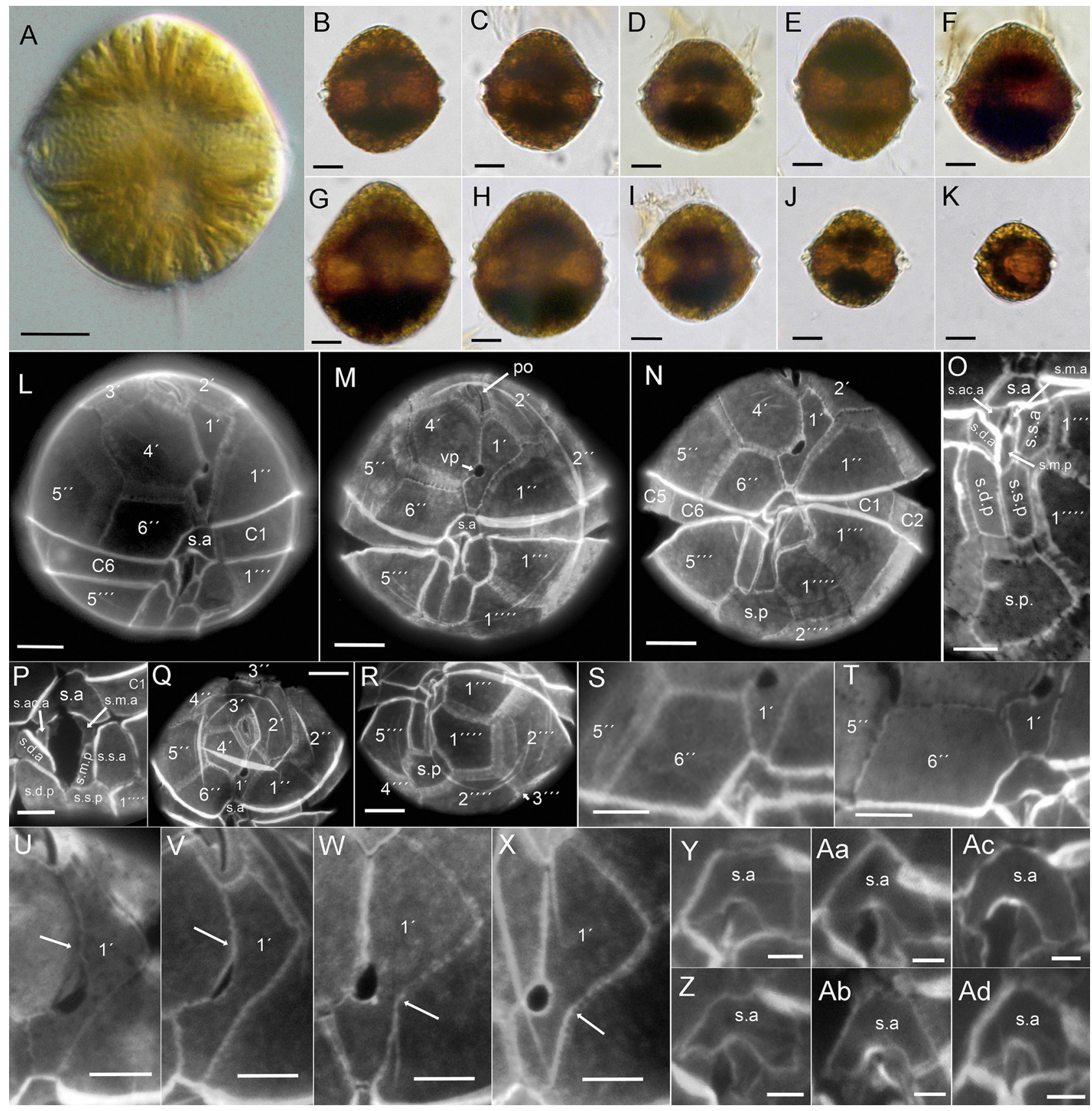

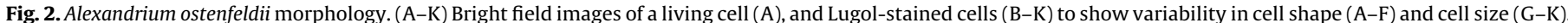

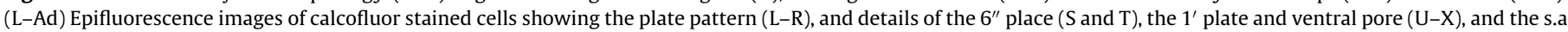

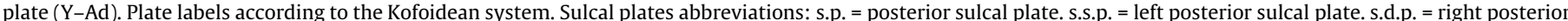

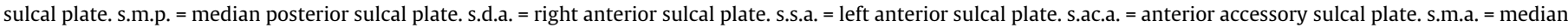
anterior sulcal plate. s.a. $=$ anterior sulcal plate. 
Table 1

Size measurements of all tested OKNL clones with length $(L)$, width $(W)$, and $L / W$ ratio. Values show mean \pm SD with the number of analyzed cells $(n)$

\begin{tabular}{lllll}
\hline Clone & $L(\mu \mathrm{m})$ & $W(\mu \mathrm{m})$ & $L / W$ ratio & $n$ \\
\hline OKNL1 & $41.7 \pm 4.1$ & $38.4 \pm 3.4$ & $1.09 \pm 0.06$ & 50 \\
OKNL2 & $41.1 \pm 2.8$ & $38.0 \pm 3.2$ & $1.08 \pm 0.06$ & 50 \\
OKNL3 & $43.1 \pm 3.9$ & $39.3 \pm 3.1$ & $1.10 \pm 0.05$ & 50 \\
OKNL4 & $39.9 \pm 3.2$ & $37.7 \pm 3.4$ & $1.06 \pm 0.05$ & 42 \\
OKNL7 & $40.1 \pm 3.1$ & $37.8 \pm 2.9$ & $1.06 \pm 0.06$ & 40 \\
OKNL8 & $40.9 \pm 3.0$ & $39.0 \pm 3.0$ & $1.05 \pm 0.04$ & 40 \\
OKNL9 & $38.6 \pm 3.5$ & $33.6 \pm 2.7$ & $1.15 \pm 0.07$ & 50 \\
OKNL10 & $41.9 \pm 3.8$ & $37.9 \pm 2.5$ & $1.11 \pm 0.07$ & 50 \\
OKNL11 & $42.1 \pm 2.9$ & $40.5 \pm 2.3$ & $1.04 \pm 0.03$ & 56 \\
OKNL12 & $39.1 \pm 4.5$ & $37.0 \pm 4.3$ & $1.06 \pm 0.05$ & 56 \\
OKNL13 & $37.9 \pm 6.1$ & $35.3 \pm 5.4$ & $1.07 \pm 0.05$ & 56 \\
OKNL14 & $40.6 \pm 4.2$ & $38.8 \pm 3.7$ & $1.04 \pm 0.04$ & 55 \\
OKNL15 & $42.7 \pm 4.4$ & $40.4 \pm 3.5$ & $1.06 \pm 0.05$ & 53 \\
OKNL16 & $41.3 \pm 3.8$ & $38.8 \pm 3.1$ & $1.07 \pm 0.05$ & 55 \\
OKNL17 & $40.2 \pm 3.9$ & $38.9 \pm 3.1$ & $1.03 \pm 0.04$ & 55 \\
OKNL18 & $34.4 \pm 3.8$ & $32.6 \pm 3.4$ & $1.06 \pm 0.05$ & 56 \\
OKNL19 & $42.3 \pm 4.1$ & $40.1 \pm 3.2$ & $1.06 \pm 0.05$ & 55 \\
OKNL20 & $39.8 \pm 4.4$ & $37.3 \pm 4.2$ & $1.07 \pm 0.05$ & 55 \\
OKNL21 & $32.5 \pm 4.2$ & $30.6 \pm 4.1$ & $1.06 \pm 0.04$ & 54 \\
OKNL22 & $40.8 \pm 3.3$ & $39.3 \pm 2.6$ & $1.04 \pm 0.05$ & 56 \\
Overall mean & $40.1 \pm 2.6$ & $37.6 \pm 2.6$ & $1.07 \pm 0.03$ & 20 \\
\hline
\end{tabular}

(Fig. 2L-R) was typical for the genus Alexandrium and the typical shape of the first apical plate and the large ventral pore (Fig. $2 \mathrm{~L}-\mathrm{N}$ ) clearly identified all isolates as Alexandrium ostenfeldii. Detailed morphometric analyses of four isolates indicated some variability in shape of the diagnostic plates $1^{\prime}, 6^{\prime \prime}$ and s.a. (Table 2). For most of the cells the right anterior margin of the first apical plate $1^{\prime}$ was straight (Fig. 2L and M), however for all four clones there were cells (up to $27 \%$ for clone OKNL11) with curved or irregular margins (Fig. 2U and V). A significant number of cells ranging from $22 \%$ to $43 \%$ had an anteriorly extended $1^{\prime}$ plate (Fig. $2 \mathrm{~W}$ and $\mathrm{X}$ ), which can explain some of the variability of the $1^{\prime}$ area (Table 2 ). The mean ventral pore area ranged from 2.3 to $4.6 \mu \mathrm{m}^{2}$ and was different between the four analyzed clones (Table 2). The shape of the anterior sulcal plate s.a. was found to be variable within all four analyzed clones. For the majority of cells the shape was classified as "A-shaped" (Fig. 2Aa and $\mathrm{Ab}$ ), but about $20 \%$ and $30 \%$ of the cells of each isolate had a "doorlatch" shaped (Fig. 2Y and Z) and a "horse-shoe" shaped (Fig. 2Ac and Ad) s.a. plate, respectively (Table 2). The s.a. plate was more wide than high with the width/height ratio of about 1.3 being quite similar for the four clones (Table 2). The terminal precingular plate $6^{\prime}$ was found to be quite variable in its width/height ratio (Fig. $2 \mathrm{~S}$ and $\mathrm{T}$ ), with a mean being even below one for clone OKNL12 (Table 2). Based on the ITS/LSU phylogenetic analyses (Fig. 3), the tested clones belonged to Group 1 of $A$. ostenfeldii.

\subsection{Toxins and lytic activity}

All 20 isolates of Alexandrium ostenfeldii produced PSP toxins with cellular quota ranging between 9.5 and $51 \mathrm{pg} \mathrm{cell}^{-1}$
(Fig. 4A). The total PSP content was significantly different (oneway ANOVA; $\left.F_{3,11}=21.3 ; P<0.001\right)$ between the four replicated clones (OKNL11, 12, 15 and 19), with an average relative standard deviation (i.e. the standard deviation relative to the average PSP content of each clone) of $10 \pm 5 \%$. The GTX and $\mathrm{C} 1 / \mathrm{C} 2$ toxins were the predominant analogs in all clones, the latter comprising around $84 \pm 5 \%$ of the total PSP content (Fig. 4B). The relative contribution of GTX2/3 was also largely comparable between all clones contributing to around $9.6 \pm 2 \%$ of the total PSP content, while STX showed a much larger variability contributing between $2.4 \%$ and $18 \%$ of the total PSP content (Fig. 4B). Among the cyclic imine toxin group, 13desmethylspirolide C (SPX-1) and gymnodimine A (data not shown), and 12-methylgymnodimine could be identified by comparison of retention time (Fig. 5) and CID spectra (Fig. 6) from A. ostenfeldii extracts with those from standard solutions. 13-desmethylspirolide D was identified by comparison with a previously published CID spectrum (Sleno et al., 2004).

The total gymnodimine content (i.e. gymnodimine A and 12methylgymnodimine) showed a large variation between clones with a 25 -fold difference between the lowest and highest values (Fig. 7A). The total gymnodimine content differed significantly between the four tested clones (one-way ANOVA; $F_{3,11}=98.2$; $P<0.001$ ), with an average relative standard deviation of $7 \pm 3 \%$. All clones predominantly produced gymnodimine A, while most clones also produced 12-methylgymnodimine with relative contributions ranging between $0.2 \%$ and $37 \%$ (Fig. $7 \mathrm{~A}$ ). The cellular quota of total SPX (expressed as SPX-1 equivalents) generally ranged between 2.4 and $4.4 \mathrm{pg}$ cell $^{-1}$, with three clones containing less than $1.8 \mathrm{pg} \mathrm{cell}^{-1}$ (Fig. 7B). The SPX included 13-desmethylspirolide C (76\% to $86 \%$ ) and 13 -desmethylspirolide D (14\% to $24 \%$, Fig. $7 \mathrm{~B}$ ). All clones also produced trace levels of several unknown SPX-like compounds (data not shown). The total SPX content significantly differed between the four tested clones (one-way ANOVA; $\left.F_{3,11}=37.1 ; P<0.001\right)$, with an average relative standard deviation of $8 \pm 2 \%$. We observed a significant correlation between the cellular quota of total PSP toxins and total SPX $(r=0.568 ; n=20 ; P=0.009)$, total PSP toxins and total gymnodimines $(r=0.472 ; n=20 ; P=0.031)$, and total SPX and total gymnodimines $(r=0.526 ; n=20 ; P=0.017)$.

All 12 selected clones induced lysis of Rhodomonas salina, with $\mathrm{EC}_{50}$ values ranging between 212 and 525 Alexandrium ostenfeldii cells $\mathrm{mL}^{-1}$ (Fig. 8A and B). The lytic response toward cellular extract were less pronounced and corresponded to 1222 to $5839 \mathrm{~A}$. ostenfeldii cells $\mathrm{mL}^{-1}$, and was even beyond the highest tested cell concentration of 15,000 cell $\mathrm{mL}^{-1}$ for stain OKNL18 (Fig. 8C). A quantitative comparison of cell lysis between whole cell culture and cell free supernatant of strain OKNL21 showed that about 70\% of the total lytic activity is present without the cells (data not shown). We did not observe a significant correlation between the $\mathrm{EC}_{50}$ values and the different cellular toxin quota.

\section{Discussion}

The morphological characteristics show a high variability within the population, supporting earlier descriptions of members

Table 2

Diagnostic plate features of four OKNL clones. Values show mean, and mean \pm SD, with the number of analyzed cells ( $n$ ).

\begin{tabular}{|c|c|c|c|c|c|c|c|c|c|c|}
\hline \multirow[t]{2}{*}{ Clone } & \multirow{2}{*}{$\begin{array}{l}\text { Shape } 1^{\prime} \text { plate } \\
\% \text { Straight }(n)\end{array}$} & \multirow{2}{*}{$\begin{array}{l}1^{\prime} \text { extension } \\
\% \text { Yes }(n)\end{array}$} & \multicolumn{4}{|l|}{ Shape s.a } & \multirow[t]{2}{*}{ Area vp $\left(\mu \mathrm{m}^{2}\right)$} & \multirow[t]{2}{*}{ Area $1^{\prime}\left(\mu \mathrm{m}^{2}\right)$} & \multirow[t]{2}{*}{$6^{\prime \prime}$ ratio $\mathrm{w} / \mathrm{h}$} & \multirow[t]{2}{*}{ s.a ratio $\mathrm{w} / \mathrm{h}$} \\
\hline & & & \% Door-latch & \% A-shaped & $\begin{array}{l}\text { \% Horseshoe- } \\
\text { shaped }\end{array}$ & $n$ & & & & \\
\hline OKNL11 & $72.6(62)$ & $21.9(64)$ & 16.1 & 55.4 & 28.6 & 56 & $4.6 \pm 1.6(44)$ & $76.6 \pm 16.2(36)$ & $1.3 \pm 0.2(45)$ & $1.3 \pm 0.2(38)$ \\
\hline OKNL12 & $86.5(37)$ & $22.2(45)$ & 24.4 & 40.0 & 35.6 & 45 & $3.0 \pm 0.8(21)$ & $52.6 \pm 13.5(16)$ & $0.9 \pm 0.1(37)$ & $1.2 \pm 0.2(21)$ \\
\hline OKNL14 & $92.1(63)$ & $42.9(63)$ & 17.9 & 53.8 & 28.2 & 78 & $2.3 \pm 1.0$ & $70.1 \pm 16.2(48)$ & $1.1 \pm 0.2(64)$ & $1.2 \pm 0.2(68)$ \\
\hline OKNL19 & $93.8(96)$ & 33.3 (99) & 14.4 & 58.9 & 26.7 & 90 & $3.3 \pm 1.0(115)$ & $76.3 \pm 16.7(90)$ & $1.1 \pm 0.1(97)$ & $1.3 \pm 0.2(88)$ \\
\hline
\end{tabular}




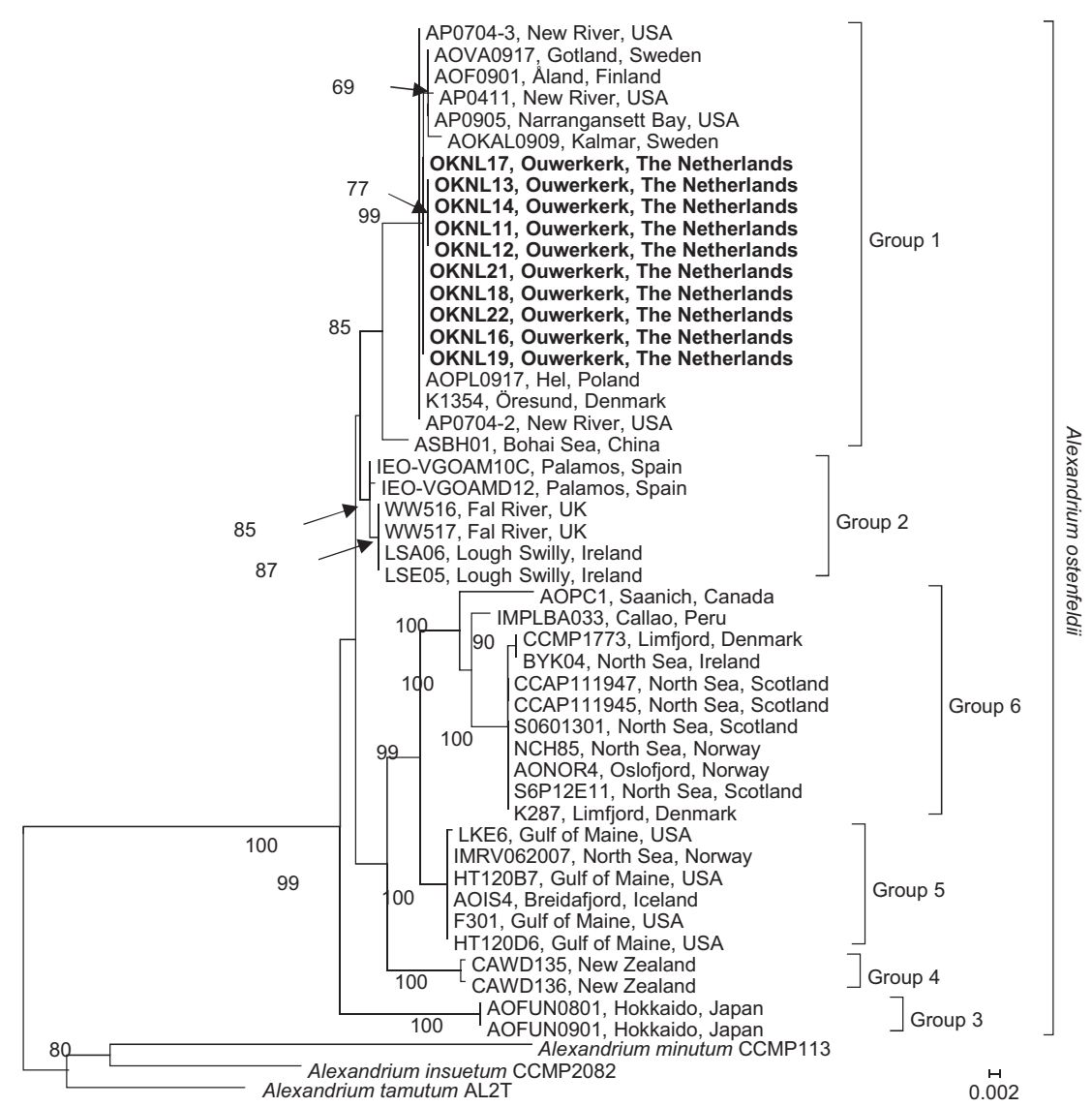

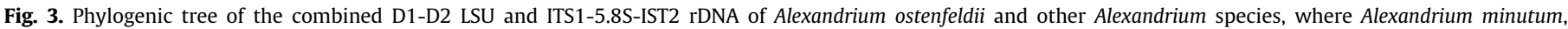

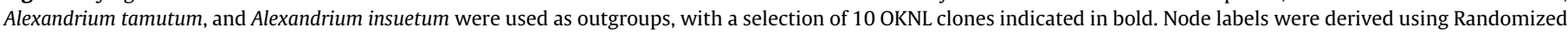
Axelerated Maximum Likelihood analyses, RAxML (Stamatakis, 2014), in GTRGAMMA with 1000× bootstrap support.

from Group 1 of Alexandrium ostenfeldii. The high variability in cell size within each clone, in combination with a relatively consistent length/width ratio of 1.1 , is in line with earlier findings for clones belonging to Group 1 (Kremp et al., 2014). About 30\% of the investigated cells showed an anteriorly extended $1^{\prime}$ plate, more common for Group 2. Previously considered as an important diagnostic plate, our analysis shows a variety of shapes for the s.a. plate within the clones, dominated by A-shaped plates generally accounting for $52 \%$, but also with up to $36 \%$ of the cells containing a horseshoe-shaped s.a. plate, previously ascribed to Alexandrium peruvianum. We thus confirm the conclusions by Kremp et al. (2014) that the diagnostic characters originally defined to separate A. ostenfeldii and A. peruvianum are more variable than previously assumed and can show considerable intra- and inter-strain variability. Furthermore, Kremp et al. (2014) showed that A. ostenfeldii and $A$. peruvianum morphotypes often had nearly identical rDNA sequences indicating that they represent extreme ends in a continuum of $A$. ostenfeldii morphotypes (Kremp et al., 2014). Nevertheless, Kremp et al. (2014) also showed that selected plate features, when tested statistically, as well as toxin profiles, differed significantly among phylogenetic clusters. Our morphometric analysis thus indicate a designation of the Dutch $A$. ostenfeldii population as members of the Group 1 (see also Kremp et al., 2014), a conclusion clearly supported by both the molecular data and the presence of PSP toxins.

The phylogenetic analysis reveals a close relationship of the Dutch Alexandrium ostenfeldii population with isolates covering a wide geographical distribution, ranging from the coastal areas in the Baltic Sea to embayments in the North-East coast of the US (Fig. 3). This geographically wide distribution may indicate recent anthropogenic-driven dispersal, or that the phylogenetic clade comprises globally distributed populations with a broad trait range similar to the Groups (I-V) of the former Alexandrium tamarense species complex (John et al., 2014). The emergence of A. ostenfeldii in the Ouwerkerkse Kreek seems to have occurred only recently, although some sporadic observations of Alexandrium sp. in the area were made in the last decade during monitoring programs (unpublished data). However, only in depth population genetics will help to evaluate a common origin and/or the potential dispersal routes of the A. ostenfeldii Group 1 populations.

Interestingly, within Alexandrium ostenfeldii Group 1, toxin profiles of the isolates from The Netherlands are most comparable to two isolates from North America, which are the only representatives which also produce PSP toxins, SPX, and gymnodimines (Van Wagoner et al., 2011; Borkman et al., 2012; Tomas et al., 2012). The Dutch isolates, however, differ in their gymnodimine composition. Specifically, the isolates from North America were reported to only produce 12-methylgymnodimine, while the OKNL isolates produce both 12-methylgymnodimine as well as gymnodimine A, a compound previously known from Karenia only (Seki et al., 1995; MacKenzie et al., 1996; Miles et al., 2000). It thus seems that the clones we report here are the first record of gymnodimine $A$ for $A$. ostenfeldii, and possess a unique combination of toxins. Whether the isolates from North America are not producing gymnodimine A, or if the levels are below detection limit requires further analyses. Generally, taking into account that advancing analytical techniques will lower the limit of detection for a multitude of toxins, future studies may show that more complex toxin profiles might generally be common for $A$. ostenfeldii populations. 

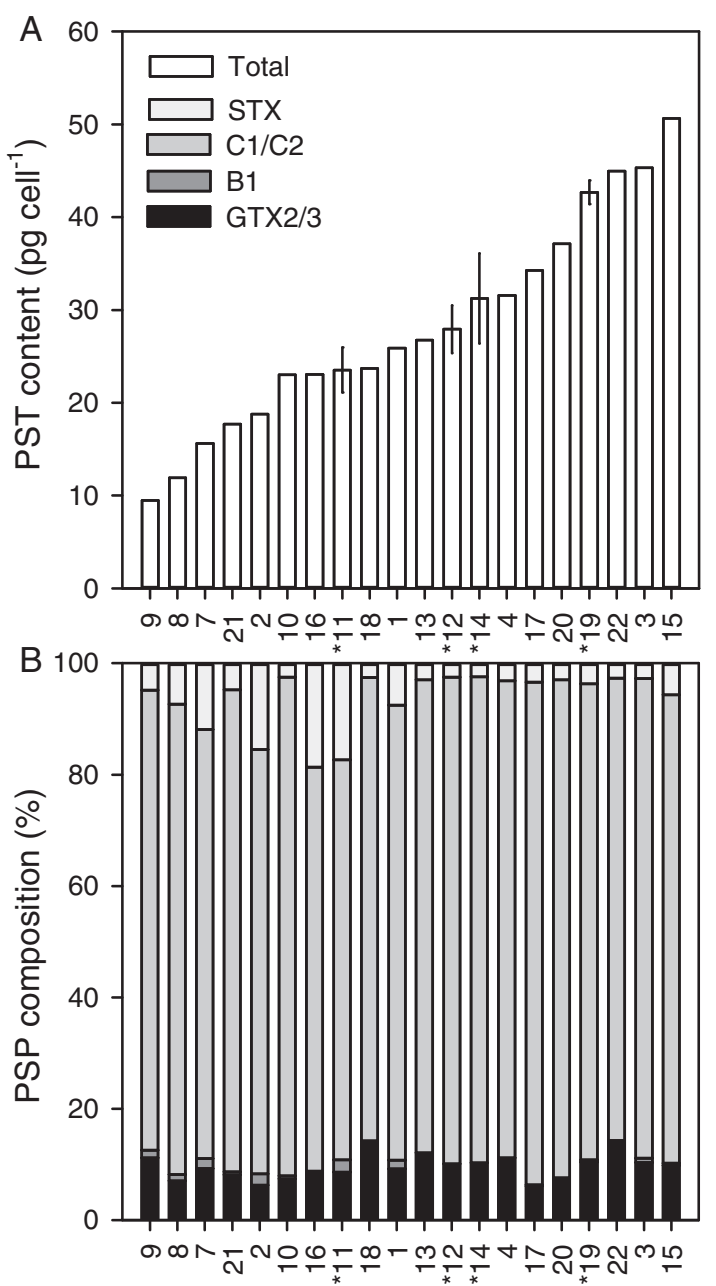

A. ostenfeldii clone number

Fig. 4. Variation in cellular PSP toxins content (A) and composition (B) in all isolated A. ostenfeldii OKNL clones. Bars show mean of technical replicates, except for OKNL11, OKNL12, OKNL14 and OKNL19, which indicate mean $\pm \operatorname{SD}(n=3)$, also denoted by an asterisk.

The cellular quota of PSP toxins fell within the range of earlier reported Alexandrium ostenfeldii and Alexandrium tamarense clones (Tillmann et al., 2009; Suikkanen et al., 2013). The predominance of $\mathrm{C} 1 / \mathrm{C} 2$ has been earlier reported for $A$. ostenfeldii clones, though the PSP toxin composition differs between isolates (Kremp et al., 2014). B1 toxins were not found in clones OKNL4, 12, 13, and 14, which may indicate that these clones lack the ability to produce B1, or that the values were below the level of detection $\left(<0.1 \mathrm{pg}\right.$ cell $\left.^{-1}\right)$. Both the cellular quota of SPX and gymnodimines are relatively low as compared to an earlier reported $A$. ostenfeldii clone (then designated to Alexandrium peruvianum) from the US East Coast (Tatters et al., 2012), while SPX quota fell within the range of several $A$. peruvianum clones from the NE Atlantic (Suikkanen et al., 2013). SPX consisted mainly of 13-desmethylspirolide $\mathrm{C}$, which was largely consistent with other clones in Group 1 and 2 of the A. ostenfeldii species complex (Kremp et al., 2014), though all OKNL clones also contained some 13-desmethylspirolide D. Clones OKNL13 and OKNL22 did not produce 12methylgymnodimine, or only very low amounts that fell below the limit of detection $\left(<0.1 \mathrm{pg} \mathrm{cell}^{-1}\right)$. We furthermore observed differences between clones with the lowest and highest detected toxin quota of about 5-fold for PSP toxins, 4-fold for SPX and
A

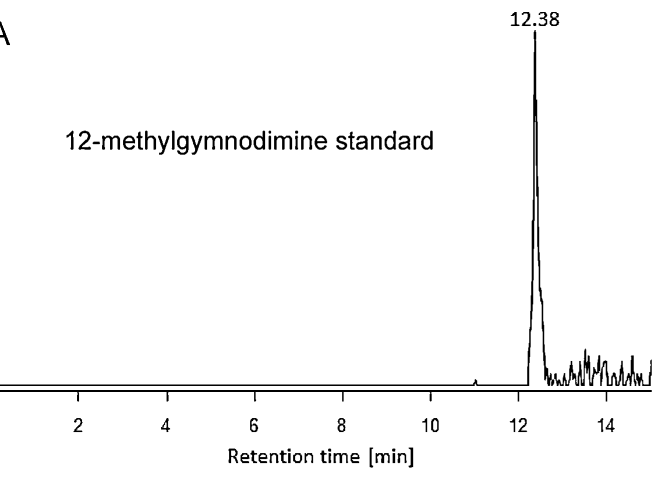

B

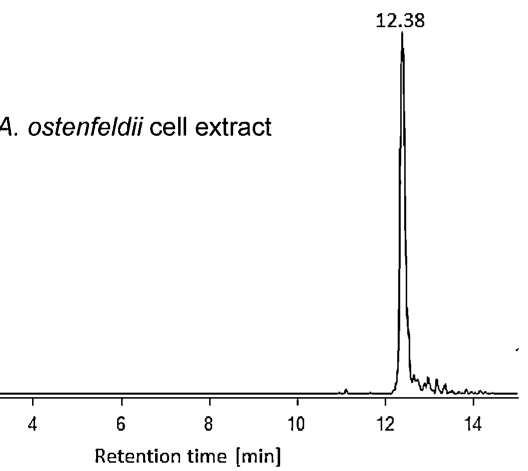

Fig. 5. Ion chromatograms ( $\mathrm{m} / \mathrm{z} 522>406)$ of (A) a 12-methylgymnodimine standard and (B) an A. ostenfeldii extract (clone OKNL3).

25 -fold for gymnodimines. Thus, our results demonstrate a high intraspecific variability in toxin quota, which is in line with earlier reports on Alexandrium sp. populations (Gribble et al., 2005; Tillmann et al., 2009; Alpermann et al., 2010; Tillmann et al., 2014).

A

12-methylgymnodimine standard

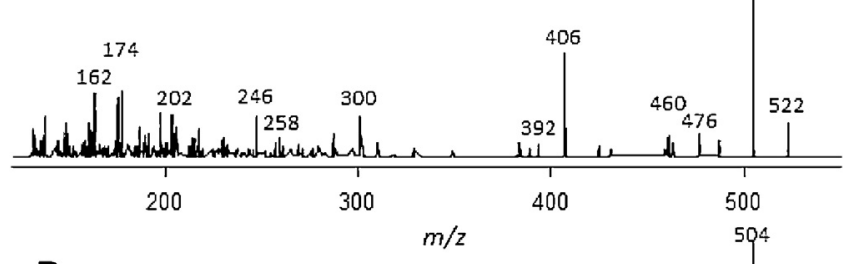

B

A. ostenfeldii cell extract

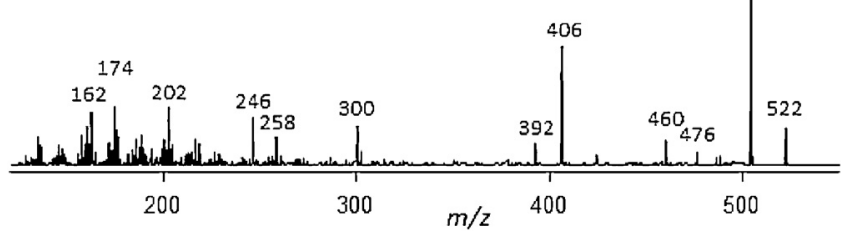

Fig. 6. CID spectra (m/z 522) of (A) a 12-methylgymnodimine standard and (B) an Alexandrium ostenfeldii extract (clone OKNL3). 

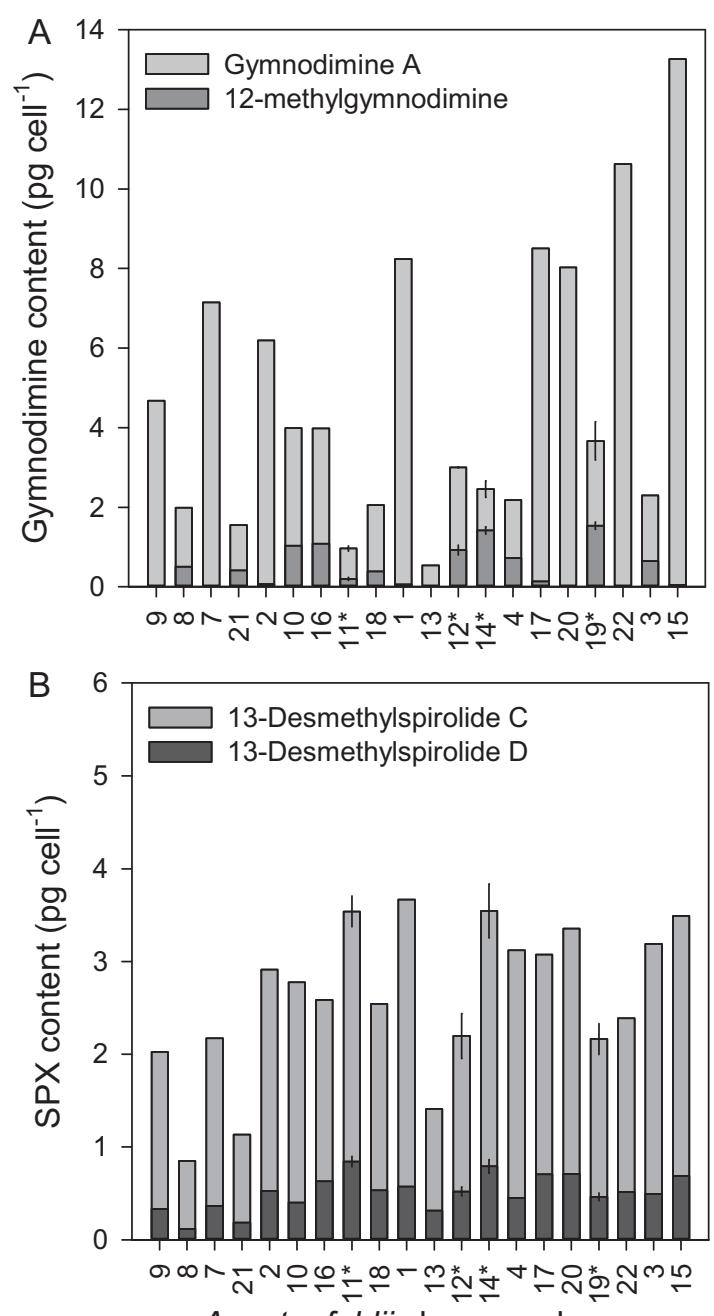

A. ostenfeldii clone number

Fig. 7. Variation in cellular gymnodimine content and composition (A), and SPX content and composition (B) in all isolated Alexandrium ostenfeldii OKNL clones. Bars show mean of technical replicates, except for OKNL11, OKNL12, OKNL14 and OKNL19, which indicate mean $\pm \operatorname{SD}(n=3)$, also denoted by an asterisk.

This variability cannot be explained by differences in growth conditions or growth phase, as all cultures were grown under the same conditions and harvested during the mid-exponential growth phase. The observed variability in toxin quota thus seems the result of genetic differences between clones.

In addition to the production of PSP toxins, spirolides, and gymnodimines, all isolates produced alleochemicals with the capacity to lyse cells of the target species Rhodomonas salina. Lytic activity of extracellular secondary metabolites is rather widespread in the genus Alexandrium (Tillmann and John, 2002) and has been shown for various Alexandrium ostenfeldii clones (Hansen et al., 1992; Tillmann et al., 2007; Tomas et al., 2012; Hakanen et al., 2014; Tillmann et al., 2014). Our correlation analyses confirm earlier comparative approaches that have shown that lytic activity is unrelated to PSP toxin (Tillmann and John, 2002) and spirolide content (Tillmann et al., 2007), and also a comparison of gymnodimine cell quota and lytic activity gave no obvious evidence that gymnodimines might contribute to the observed cell lysis of $R$. salina.

With $\mathrm{EC}_{50}$ values from 0.18 to $0.5 \times 10^{3}$ cells $\mathrm{mL}^{-1}$ the Dutch population seem to possess a comparable lytic activity as other Alexandrium ostenfeldii isolates of other phylogenetic groups. Their $\mathrm{EC}_{50}$ values have been shown to range from 0.2 to $1.9 \times 10^{3}$ cells $\mathrm{mL}^{-1}$ (Tillmann et al., 2007; Hakanen et al., 2014)
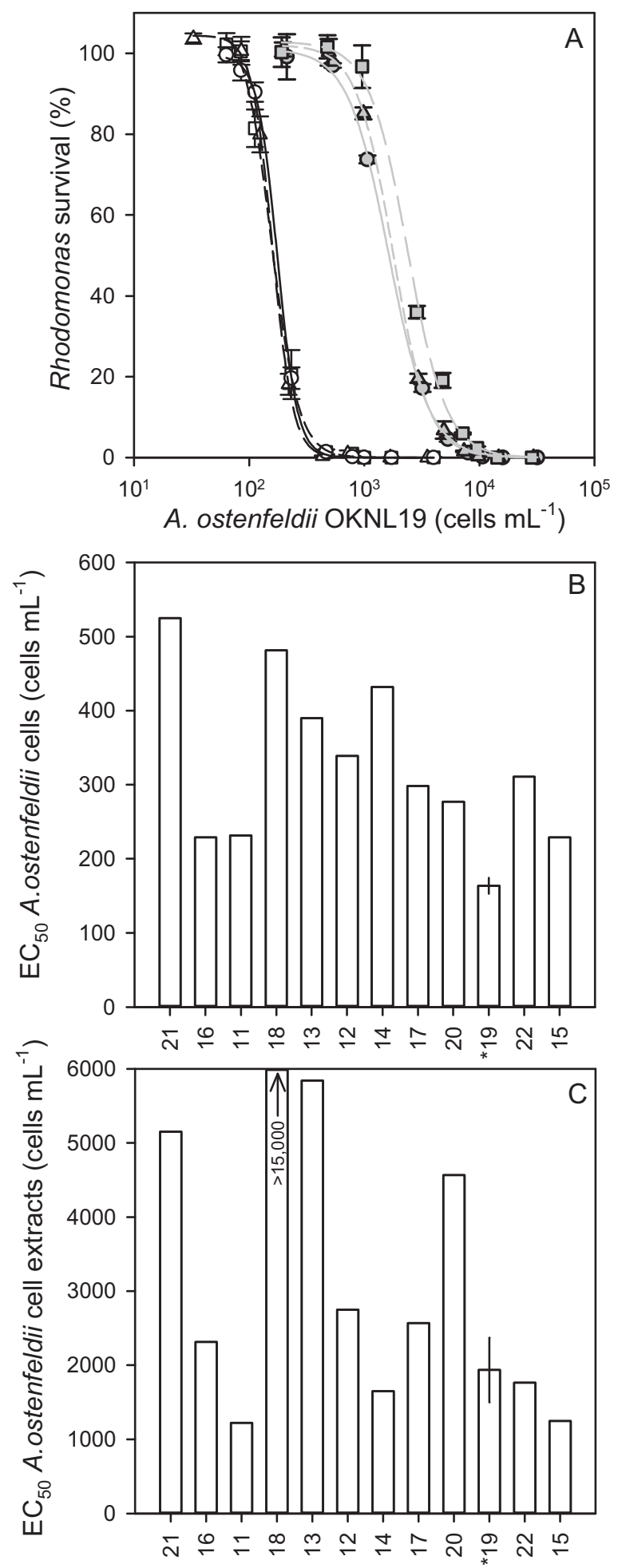

A. ostenfeldii OKNL clone number

Fig. 8. Variation in allelopathic activities in a selection of $A$. ostenfeldii OKNL clones expressed as $\mathrm{EC}_{50}$ values of whole cell cultures based on Rhodomonas salina survival (\%), with typical dose-response curves (A; circles, squares and triangles represent triplicate cultures with mean $\pm \mathrm{SD}(n=3)$, with open symbols for whole culture and gray filled symbols for cell extract), and an overview of the $\mathrm{EC}_{50}$ values of the tested clones based on whole cell cultures (B), and based on cell extracts (C). Bars show mean of technical replicates $(n=3)$, except for OKNL19, which indicates mean $\pm \operatorname{SD}(n=3)$ based on the triplicate cultures shown in (A), also denoted by an asterisk. 
suggesting comparable lytic activities within the species $A$. ostenfeldii. $\mathrm{EC}_{50}$ values for hemolyis of $A$. ostenfeldii Group I from the USA coast given by Tomas et al. (2012) and Tatters et al. (2012) for the same isolate $\left(14 \times 10^{3}\right.$ and $7 \times 10^{3}$ cells, respectively; values given as "cells" and not as a concentration) are more difficult to compare and refer to cell extracts. By using an erythrocyte lysis assay, Tomas et al. (2012) found only limited lysis in cell free supernatant of the A. ostenfeldii clones from coastal North Carolina, whereas particularly cell pellets had the highest lytic activity. The authors thus concluded that the lytic agents were most likely intracellular or membrane bound (Tomas et al., 2012). However, our data clearly show that lytic activity of cellular extracts was, with a mean factor of 12 (range: 4-30), remarkably lower compared to the lytic activity of whole cell cultures. The observed 30\% loss of lytic activity when removing the cells might indicate a continuous release of lytic compounds during the bioassay incubation, but might also be due to loss of lytic compounds during the centrifugation step, as such compounds have been shown to adsorb to plastic material (Ma et al., 2009, 2010). In any case, our data show that the majority of lytic activity of $A$. ostenfeldii is excreted and acting extracellular, underlining a rather unspecific role in grazer impairment and competition (Cembella, 2003; Legrand et al., 2003). Nevertheless, lytic compounds produced by $A$. ostenfeldii may also be involved in cell-to-cell interactions, e.g. in prey capture and resource acquisition via mixotrophy.

Whole cell lytic activity varied roughly two-fold among clones. The intraspecific variability in lytic activity thus seems to be smaller as compared to multi-clone comparisons of Alexandrium tamarense (Alpermann et al., 2010) and Alexandrium ostenfeldii (Hakanen et al., 2014; Tillmann et al., 2014), and might indicate that high lytic activity was a trait positively selected for in the sampled bloom population. During the bloom period in the Ouwerkerkse Kreek, cell concentrations of $A$. ostenfeldii were well above 1000 cell $\mathrm{mL}^{-1}$ (Fig. 1C) and thus far above the concentration that was shown to cause significant cell lysis of Rhodomonas salina in our bioassays. Although the role of lytic compounds for bloom initiation, at much lower cell concentrations, is more difficult to evaluate, deleterious effects of lytic extracellular compounds on both competitors and grazers likely play an important role in the success of Alexandrium blooms (John et al., 2015).

From a human health perspective, the toxicity of an Alexandrium bloom is determined by the population densities, and the amounts and relative toxicities of toxins that are produced. The Alexandrium ostenfeldii population in the Ouwerkerkse Kreek reached very high cell densities of up to 4500 cells $\mathrm{mL}^{-1}$ (Fig. 1C), and will be of particular risk if dominated by the clones with high cellular toxin quota. However, the toxin composition in all clones consisted predominantly of the least toxic $\mathrm{C} 1 / \mathrm{C} 2$. These C-toxins are hardly found in molluscs as they are readily desulfonated by enzymatic activity (Krock et al., 2007). This will convert C-toxins into the more toxic GTX which may potentially lead to high toxicities of exposed shellfish. The population of $A$. ostenfeldii for Ouwerkerkse Kreek produces two different toxin classes at the same time, and interactive effects among both toxin classes cannot be ruled out as, to the best of our knowledge, no studies have been conducted to investigate synergistic effects between different classes of neurotoxins, such as PSP toxins and cyclic imine toxins. Risks of blooms may furthermore be affected by environmental driven changes in the cellular toxin quota, for instance induced by changes in nutrient availabilities, $\mathrm{pCO}_{2}$ and temperature (Kremp et al., 2012; Tatters et al., 2013; Van de Waal et al., 2013, 2014).

In conclusion, our study shows that the dense bloom in The Netherlands was formed by Group 1 of the Alexandrium ostenfeldii species complex and thus highlights a new example of the bloom forming potency of this group around the world. The population contained a highly diverse cocktail of various neurotoxins, which underlines the threat of these blooms for important shellfish production areas in The Netherlands. Growth of isolates from this bloom under fixed laboratory settings was relatively slow, suggesting that allelopathy and presumably a reduced population loss by grazing, played a substantial role in bloom formation and persistence. Our data also demonstrate a high intra-specific variability with respect to toxin quota in the Dutch $A$. ostenfeldii population, as was earlier also reported for other Alexandrium populations (Alpermann et al., 2010). Such a high phenotypic variability may add to the success of genotypically highly diverse $A$. ostenfeldii blooms, and make populations resilient to changes in environmental and climatic conditions.

\section{Acknowledgements}

The authors thank Pia Tahvanainen from the University of Helsinki for sharing Alexandrium ostenfeldii sequences prior to their availability in GenBank. We thank Annegret Müller for analyses of PSP toxins and Nancy Kühne for technical support with sequencing. We are grateful to Cynthia de Kruijff-Van der Voorn from Waterschap Scheldestromen, and Suzanne Wiezer, Dennis Waasdorp, and Sven Teurlincx from the Netherlands Institute of Ecology (NIOO-KNAW) for their technical support. Kirsi Harju from the University of Helsinki is acknowledged for providing a standard solution of 12-methylgymnodimine.[SS]

\section{Appendix A. Supplementary data}

Supplementary data associated with this article can be found, in the online version, at doi:10.1016/j.hal.2015.08.002.

\section{References}

Alpermann, T.J., Tillmann, U., Beszteri, B., Cembella, A.D., John, U., 2010. Phenotypic variation and genotypic diversity in a planktonic population of the toxigenic marine dinoflagellate Alexandrium tamarense (Dinophyceae). J. Phycol. 46 (1), $18-32$

Anderson, D.M., Alpermann, T.J., Cembella, A.D., Collos, Y., Masseret, E., Montresor, M., 2012. The globally distributed genus Alexandrium: multifaceted roles in marine ecosystems and impacts on human health. Harmful Algae 14, 10-35.

Anderson, D.M., Glibert, P.M., Burkholder, J.M., 2002. Harmful algal blooms and eutrophication: nutrient sources, composition, and consequences. Estuaries 25 (4B), 704-726

Borkman, D.G., Smayda, T.J., Tomas, C.R., York, R., Strangman, W., Wright, J.L.C., 2012. Toxic Alexandrium peruvianum (Balech and de Mendiola) Balech and Tangen in Narragansett Bay, Rhode Island (USA). Harmful Algae 19, 92-100.

Burson, A., Matthijs, H.C.P., de Bruijne, W., Talens, R., Hoogenboom, R., Gerssen, A., Visser, P.M., Stomp, M., Steur, K., van Scheppingen, Y., Huisman, J., 2014. Termination of a toxic Alexandrium bloom with hydrogen peroxide. Harmful Algae 31, 125-135.

Cembella, A.D., 1998. Ecophysiology and metabolism of paralytic shellfish toxins in marine microalgae. In: Anderson, D.M., Cembella, A.D., Hallegraeff, G.M. (Eds.), Physiological Ecology of Harmful Algal Blooms. Springer-Verlag, Berlin Heidelberg, Heidelberg, Germany, pp. 281-403.

Cembella, A.D., 2003. Chemical ecology of eukaryotic microalgae in marine ecosystems. Phycologia 42 (4), 420-447.

Cembella, A.D., Lewis, N.I., Quilliam, M.A., 2000. The marine dinoflagellate Alexandrium ostenfeldii (Dinophyceae) as the causative organism of spirolide shellfish toxins. Phycologia 39 (1), 67-74.

Ciminiello, P., Dell'Aversano, C., Fattorusso, E., Magno, S., Tartaglione, L., Cangini, M. Pompei, M., Guerrini, F., Boni, L., Pistocchi, R., 2006. Toxin profile of Alexandrium ostenfeldii (Dinophyceae) from the Northern Adriatic Sea revealed by liquid chromatography-mass spectrometry. Toxicon 47 (5), 597-604.

Diener, M., Erler, K. Hiller, S., Christian, B., Luckas, B., 2006. Determination of paralytic shellfish poisoning (PSP) toxins in dietary supplements by application of a new HPLC/FD method. Eur. Food Res. Technol. 224 (2), 147-151.

Fritz, L., Triemer, R.E., 1985. A rapid simple technique utilizing Calcofluor White M2R for the visualization of dinoflagellate thecal plates. J. Phycol. 21, 662-664.

Gribble, K.E., Keafer, B.A., Quilliam, M.A., Cembella, A.D., Kulis, D.M., Manahan, A., Anderson, D.M., 2005. Distribution and toxicity of Alexandrium ostenfeldii 
(Dinophyceae) in the Gulf of Maine, USA. Deep Sea Res. II Top. Stud. Oceanogr. $52(19-21), 2745-2763$.

Hakanen, P., Suikkanen, S., Franzen, J., Franzen, H., Kankaanpaa, H., Kremp, A., 2012. Bloom and toxin dynamics of Alexandrium ostenfeldii in a shallow embayment at the SW coast of Finland, northern Baltic Sea. Harmful Algae 15, 91-99.

Hakanen, P., Suikkanen, S., Kremp, A., 2014. Allelopathic activity of the toxic dinoflagellate Alexandrium ostenfeldii: intra-population variability and response of co-occurring dinoflagellates. Harmful Algae 39, 287-294.

Hansen, P.J., Cembella, A.D., Moestrup, O., 1992. The marine dinoflagellate Alexandrium ostenfeldii: paralytic shellfish toxin concentration, composition, and toxicity to a tintinnid ciliate. J. Phycol. 28 (5), 597-603.

Heisler, J., Glibert, P.M., Burkholder, J.M., Anderson, D.M., Cochlan, W., Dennison, W.C., Dortch, Q., Gobler, C.J., Heil, C.A., Humphries, E., Lewitus, A., Magnien, R. Marshall, H.G., Sellner, K., Stockwell, D.A., Stoecker, D.K., Suddleson, M., 2008. Eutrophication and harmful algal blooms: a scientific consensus. Harmful Algae 8 (1), 3-13.

John, U., Cembella, A., Hummert, C., Elbrächter, M., Groben, R., Medlin, L., 2003. Discrimination of the toxigenic dinoflagellates Alexandrium tamarense and A. ostenfeldii in co-occurring natural populations from Scottish coastal waters. Eur. J. Phycol. 38 (1), 25-40.

John, U., Litaker, R.W., Montresor, M., Murray, S., Brosnahan, M.L., Anderson, D.M., 2014. Formal revision of the Alexandrium tamarense species complex (Dinophyceae) taxonomy: the Introduction of five species with emphasis on molecular-based (rDNA) classification. Protist 165 (6), 779-804.

John, U., Tillmann, U., Hülskötter, J., Alpermann, T.J., Wohlrab, S., Van de Waal, D.B., 2015. Intraspecific facilitation by allelochemical mediated grazing protection within a toxigenic dinoflagellate population. Proc. R. Soc. Lond. Ser. B: Biol. Sci. 282 (1798)

Katoh, K., Kuma, K., Toh, H., Miyata, T., 2005. MAFFT version 5: improvement in accuracy of multiple sequence alignment. Nucleic Acids Res. 33 (2), 511-518.

Keller, M.D., Selvin, R.C., Claus, W., Guillard, R.R.L., 1987. Media for the culture of oceanic ultraphytoplankton. J. Phycol. 23 (4), 633-638.

Kremp, A., Godhe, A., Egardt, J., Dupont, S., Suikkanen, S., Casabianca, S., Penna, A., 2012. Intraspecific variability in the response of bloom-forming marine microalgae to changed climate conditions. Ecol. Evol. 2 (6), 1195-1207.

Kremp, A., Tahvanainen, P., Litaker, W., Krock, B., Suikkanen, S., Leaw, C.P., Tomas, C., 2014. Phylogenetic relationships, morphological variation, and toxin patterns in the Alexandrium ostenfeldii (Dinophyceae) complex: implications for species boundaries and identities. J. Phycol. 50 (1), 81-100.

Krock, B., Seguel, C.G., Cembella, A.D., 2007. Toxin profile of Alexandrium catenella from the Chilean coast as determined by liquid chromatography with fluorescence detection and liquid chromatography coupled with tandem mass spectrometry. Harmful Algae 6 (5), 734-744.

Legrand, C., Rengefors, K., Fistarol, G.O., Graneli, E., 2003. Allelopathy in phytoplankton - biochemical, ecological and evolutionary aspects. Phycologia 42 (4), 406-419.

Ma, H.Y., Krock, B., Tillmann, U., Cembella, A., 2009. Preliminary characterization of extracellular allelochemicals of the toxic marine dinoflagellate Alexandrium tamarense using a Rhodomonas salina bioassay. Mar. Drugs 7 (4), 497-522.

Ma, H.Y., Krock, B., Tillmann, U., Cembella, A., 2010. Towards characterization of lytic compound (s) produced by Alexandrium tamarense. In: Ho, K.C., Zhou, M.J., Qi, Y.Z. (Eds.), Proceedings of the 13th International Conference on Harmful Algae. Environmental Publication House, Hong Kong, pp. 142-146.

MacKenzie, A.L., Haywood, A.J., Adamson, J., Truman, P., Till, D., Seki, T., Satake, M., Yasumoto, T., 1996. Gymnodimine contamination of shellfish in New Zealand. In: Yasumoto, T., Oshima, Y., Fukuyo, Y. (Eds.), Harmful and Toxic Algal Blooms: Proceedings of the Seventh International Conference on Toxic Phytoplankton, Sendai, Japan, 12-16 July 1995. UNESCO, Intergovernmental Oceanographic Commission, Paris, France, pp. 97-100.

Miles, C.O., Wilkins, A.L., Stirling, D.J., MacKenzie, A.L., 2000. New analogue of gymnodimine from a Gymnodinium species. J. Agric. Food Chem. 48 (4), 1373-1376.

Munday, R., Quilliam, M.A., LeBlanc, P., Lewis, N., Gallant, P., Sperker, S.A., Ewart, H.S., MacKinnon, S.L., 2012. Investigations into the toxicology of spirolides, a group of marine phycotoxins. Toxins 4 (1), 1-14.

Munday, R., Towers, N.R., Mackenzie, L., Beuzenberg, V., Holland, P.T., Miles, C.O. 2004. Acute toxicity of gymnodimine to mice. Toxicon 44 (2), 173-178.

Seki, T., Satake, M., Mackenzie, L., Kaspar, H.F., Yasumoto, T., 1995. Gymnodimine, a new marine toxin of unprecedented structure isolated from New-Zealand oysters and the dinoflagellate, Gymnodinium sp. Tetrahedron Lett. 36 (39), 7093-7096.
Shimizu, Y., 1996. Microalgal metabolites: a new perspective. Annu. Rev. Microbiol. $50,431-465$

Sleno, L., Chalmers, M.J., Volmer, D.A., 2004. Structural study of spirolide marine toxins by mass spectrometry - Part II. Mass spectrometric characterization of unknown spirolides and related compounds in a cultured phytoplankton extract. Anal. Bioanal. Chem. 378 (4), 977-986.

Stamatakis, A., 2014. RAxML version 8: a tool for phylogenetic analysis and postanalysis of large phylogenies. Bioinformatics 30 (9), 1312-1313.

Stamatakis, A., Ludwig, T., Meier, H., 2005. RAxML-III: a fast program for maximum likelihood-based inference of large phylogenetic trees. Bioinformatics 21 (4), 456-463.

Suikkanen, S., Kremp, A., Hautala, H., Krock, B., 2013. Paralytic shellfish toxins or spirolides? The role of environmental and genetic factors in toxin production of the Alexandrium ostenfeldii complex. Harmful Algae 26, 52-59.

Tatters, A.O., Flewelling, L.J., Fu, F.X., Granholm, A.A., Hutchins, D.A., 2013. High $\mathrm{CO}_{2}$ promotes the production of paralytic shellfish poisoning toxins by Alexandrium catenella from Southern California waters. Harmful Algae 30, 37-43.

Tatters, A.O., Van Wagoner, R.M., Wright, J.L.C., Tomas, C.R., 2012. Regulation of spiroimine neurotoxins and hemolytic activity in laboratory cultures of the dinoflagellate Alexandrium peruvianum (Balech \& Mendiola) Balech \& Tangen. Harmful Algae 19, 160-168.

Tillmann, U., Alpermann, T., John, U., Cembella, A., 2008. Allelochemical interactions and short-term effects of the dinoflagellate Alexandrium on selected photoautotrophic and heterotrophic protists. Harmful Algae 7 (1), 52-64.

Tillmann, U., Alpermann, T.L., da Purificacao, R.C., Krock, B., Cembella, A., 2009. Intra-population clonal variability in allelochemical potency of the toxigenic dinoflagellate Alexandrium tamarense. Harmful Algae 8 (5), 759-769.

Tillmann, U., Hansen, P.J., 2009. Allelopathic effects of Alexandrium tamarense on other algae: evidence from mixed growth experiments. Aquat. Microb. Ecol. 57 (1), 101-112.

Tillmann, U., John, U., 2002. Toxic effects of Alexandrium spp. on heterotrophic dinoflagellates: an allelochemical defence mechanism independent of PSPtoxin content. Mar. Ecol. Prog. Ser. 230, 47-58.

Tillmann, U., John, U., Cembella, A., 2007. On the allelochemical potency of the marine dinoflagellate Alexandrium ostenfeldii against heterotrophic and autotrophic protists. J. Plankton Res. 29 (6), 527-543.

Tillmann, U., Kremp, A., Tahvanainen, P., Krock, B., 2014. Characterization of spirolide producing Alexandrium ostenfeldii (Dinophyceae) from the western Arctic. Harmful Algae 39, 259-270

Tomas, C.R., van Wagoner, R., Tatters, A.O., White, K.D., Hall, S., Wright, J.L.C., 2012. Alexandrium peruvianum (Balech and Mendiola) Balech and Tangen a new toxic species for coastal North Carolina. Harmful Algae 17, 54-63.

Troost, T.A., Wijsman, J.W.M., Saraiva, S., Freitas, V., 2010. Modelling shellfish growth with dynamic energy budget models: an application for cockles and mussels in the Oosterschelde (southwest Netherlands). Philos. Trans. R. Soc. Lond. Ser. B: Biol. Sci. 365 (1557), 3567-3577.

van Broekhoven, W., Troost, K., Jansen, H., Smaal, A., 2014. Nutrient regeneration by mussel Mytilus edulis spat assemblages in a macrotidal system. J. Sea Res. 88 36-46.

Van de Waal, D.B., Eberlein, T., John, U., Wohlrab, S., Rost, B., 2014. Impact of elevated $\mathrm{pCO}_{2}$ on paralytic shellfish poisoning toxin content and composition in Alexandrium tamarense. Toxicon 78, 58-67.

Van de Waal, D.B., Tillmann, U., Zhu, M.M., Koch, B.P., Rost, B., John, U., 2013. Nutrient pulse induces dynamic changes in cellular C:N:P, amino acids, and paralytic shellfish poisoning toxins in Alexandrium tamarense. Mar. Ecol. Prog. Ser. 493, 57-69.

van der Fels-Klerx, H.J., Adamse, P., Goedhart, P.W., Poelman, M., Pol-Hofstad, I.E. van Egmond, H., Gerssen, A., 2011. Monitoring phytoplankton and marine biotoxins in production waters of the Netherlands: results after one decade. Food Addit. Contam.: Part A Chem. Anal. Control Expo. Risk Assess. 29 (10), 1616-1629.

Van Wagoner, R.M., Misner, I., Tomas, C.R., Wright, J.L.C., 2011. Occurrence of 12 methylgymnodimine in a spirolide-producing dinoflagellate Alexandrium peruvianum and the biogenetic implications. Tetrahedron Lett. 52 (33), 4243-4246.

Wang, D.Z., 2008. Neurotoxins from marine dinoflagellates: a brief review. Mar. Drugs 6 (2), 349-371.

Wiberg, G.S., Stephenson, N.R., 1960. Toxicologic studies on paralytic shellfish poison. Toxicol. Appl. Pharmacol. 2 (6), 607-615

Wiese, M., D’Agostino, P.M., Mihali, T.K., Moffitt, M.C., Neilan, B.A., 2010. Neurotoxic alkaloids: saxitoxin and its analogs. Mar. Drugs 8 (7), 2185-2211. 